\begin{tabular}{|c|c|c|}
\hline \multirow{2}{*}{\multicolumn{2}{|c|}{$\frac{\text { DE }}{\bar{C}}$ DE GRUYTER }} & ECONOMIC THEMES (2015) 53 (4): 519-534 \\
\hline & & DOI 10.1515/ethemes-2015-0030 \\
\hline
\end{tabular}

\title{
CAN A MULTINATIONAL COMPANY CREATE A REAL ESTATE "BUBBLE" AT THE LOCAL LEVEL? THE CASE OF FIAT AND CITY OF KRAGUJEVAC
}

\author{
Nikola Makojević \\ Faculty of Economics, University of Kragujevac, Serbia \\ 凶makojevic@kg.ac.rs \\ Petar Veselinović \\ Faculty of Economics, University of Kragujevac, Serbia \\ $\bowtie$ pveselinovic@kg.ac.rs \\ Ljubina Kalinić \\ PhD Candidate, Faculty of Economics, University of Kragujevac, Serbia \\ $\bowtie$ ljubina.kalinic@gmail.com \\ UDC \\ 339.13.017: \\ 347.235 \\ (497.11) \\ Original \\ scientific paper

\begin{abstract}
The aim of the paper is to analyze the recent dramatic increase in housing prices in Kragujevac, related to the opening of a multinational company facility. The main question is whether increasing house prices have been driven by market fundamentals or by speculative behaviour of the market players. We have decomposed variables influencing house prices in Kragujevac into supply and demand driven fundamentals to explore speculative 'bubbles' and detected the evidence of irrationally exuberant investors (constructors and buyers). The findings show a lack of rational behaviour among market players, absence of fundamentaldriven influence on real estate prices and expectancy-driven prices. The main characteristic is a strong relationship between price and rental price with no significant change in price-rent ratio.
\end{abstract}

Received:

10.02.2015

Accepted:

24.09.2015
Key words: real estate market, fundamentals, price-rent ratio, irrational expectations, multinational company

\section{Introduction}

Kragujevac, as the first capital of Serbia, today represents an economic, political and cultural centre of the region of Šmadija, and it is one of the biggest cities in Serbia. In the previous fifty years, it has been the regional centre of the 
automobile industry in the Balkans. Demographic trends for the last five decades have been quite favourable for the development of Kragujevac with a constant increase of population. Economic conditions were not favourable during the 1990s and the first eight years of the transition process (2000-2008). The number of employees declined, number of closed-down factories increased or had negative results. Such economic situation was a result of the strong concentration and dependence on the car factory, which operated successfully until the falling apart of the country and the crisis of the 1990s. During the first years of transition, it was clear that the car factory cannot survive without a strong partnership with a foreign manufacturer.

After long negotiations, in 2008, the state reached a deal with Italian car manufacturer FIAT S.p.a. on joint investment in a new plant where production of a new model 500L started in 2012. The arrival of the multinational car manufacturer to Kragujevac led to significant changes in the development of the overall economy of the city, including the changes in the real estate market. Namely, the arrival of this company caused a considerable increase in prices of the existing real estate, increase in the prices of rentals, as well as a growth of newly constructed buildings. However, after 5 years, the situation has changed, the bubble burst and today we face decreased prices and increase in unsold real estate assets.

The present paper is organized as follows: the second part contains the review of literature in the given area; fundamental factors used in the research, as well as the research methodology, based on the linear regression and Step Wise regression methodology, are described in the part three; the fourth part gives the results of the empirical research and their analysis and discussion on them is given in the part five of the paper; the final part of the paper provides concluding remarks.

\section{Literature Review}

Changes in the prices of real estate enhance fluctuations in the economy on the regional as well as on the local level, thus influencing financial stability and well-being of companies and households. Therefore, a stable relation of real estate prices and the economy is of a huge importance. Construction industry influences the economy of each country because it has a considerable contribution to the added value and it employs a big number of workers. In the majority of developed economies in the world, the price cycles most often match the loan and business cycles (Igan et al., 2011). This indicates that fluctuations in the construction and prices of real estate create waves in the economy through the influence on spending and loaning. Therefore, it can be said that the housing sector is a source of shocks in the economy, taking into consideration the delay in the response of supply to the shocks of demand. 
A big number of fundamental factors can influence the price of real estate. Those are the factors referring to supply and factors referring to demand and they can be measured using macroeconomic variables, that is, indicators (Hui, Shen, 2006; Shen, Hui, Liu, 2005). As for the supply, attention is paid to the costs of construction, organization of production, the price of land, geographical and governmental restrictions on development; and as for the demand attention is paid to demographic trends, income of households or to employment, interest rates, changes in location, size of the market, households preferences etc.

Each divergence of real estate prices from their fundamental value is defined as a "bubble", and there are many definitions of this term. The most difficult task is to establish whether the increase of real estate prices is economically based or it is connected with the irrational behaviour of economic entities. In literature there is the confirmation that the real estate bubble can be defined in three broad categories. Statistically, a real estate bubble is a very high growth of prices and accordingly price growth is qualified as bubble caused by the extended growth of income (IMF, 2003). The second definition refers to the situation of a bubble existing when real estate prices exceed the basic value to a considerable amount (Cochrane, 2001). Namely, entities on the market see the purchase of a real estate as a source of income in the future, which leads to the increase of prices. The third definition points to the existence of a bubble if real estate prices are above their long-lasting balanced level (Fernández-Kranz, Hon, 2006; Gallin, 2003), and the growth is caused by temporary demand shocks on the market.

Most commonly used method of establishing the existence of a bubble in the real estate market is comparison of real estate prices and fundamental factors. In literature dealing with housing bubble income, construction costs, population and interest rate are seen as fundamentals (Ren et al., 2012). A real estate bubble most often occurs with the increase of demand over a longer period, which, on the other hand, cannot be covered by the existing supply. Investors believe that they can make a profit fast which is the reason they enter the market, thus additionally increasing the demand. All these factors cause the increase of prices, but usually also bigger investments in the construction sector. However, at a certain moment, the demand shall start stagnating or decreasing, while at the same time the supply grows, which causes sudden fall of real estate prices with high probability that the bubble shall "burst".

Stigliz (1990) sees a bubble when price goes up because of investors' belief about rising in selling prices without justification in fundamental factor changes. Such behaviour is psychologically driven and economic fundamentals are not a significant driven force. Situation when bubble exists can be explained by irrational optimistic expectations (Shiller, 2000) or rational expatiation that investors are able to sell overvalued asset in the future (Flood, Hodrick, 1990). "Growing" bubbles are characterized by a continuous growth of prices over a 
longer period and incomes which exceed the average capital incomes in the economy. Some authors found that people's different beliefs about future returns imply different evaluation of assets (Burnside, Eichenbaum, Rebelo, 2011). In case of housing, beliefs about future value and rental condition can determine a price above the fundamentally explained one.

According to the relevant literature, it can be concluded that real estate prices in normal conditions must go in accordance with the fundamental factors, if we do not want to qualify the situation on the market as a bubble. On the contrary, every divergence of prices, which is not justified, that is, which is not caused by factors related to supply and demand, can be seen as a bubble, expanding very quickly to the rest of the economy with negative effects on households and companies.

\section{Data and Methodology}

Following the cycles of rises and falls of real estate prices in certain countries, regions and local areas, it has been established that a price bubble can be caused by changes of various fundamental factors; therefore many indicators have to be taken into consideration on the micro and macro level. Having in mind the trends in the real estate market in Kragujevac, the subject of research is directed to examining and analysis of the considerable increase of real estate prices in the period from 2007 until 2013, which may be connected with the arrival of the multinational company. The main question which occurs is whether the real estate prices increase was caused by fundamental factors or by speculative behaviour of entities on the market. Pursuant to the defined goal and subject of the research, the paper shall test the following research hypotheses:

$\mathrm{H}_{1}$ : The arrival of the multinational company has led to the rise of prices on the real estate market.

$\mathrm{H}_{2}$ : The change of prices cannot be explained by fundamental factors.

The literature defined several fundamentals as tools for understanding 'bubble' at the real estate market. These are income, rental price and population number. In our research, we included income (measured by average gross wage) and rental price (measured by average rental price per square meter). Besides, we expanded the number of fundamentals through number of units sold, construction costs per square meter and average interest rate on mortgage loans. For the purpose of the research, we have divided all fundamentals into supplyand demand-based ones. The supply-based fundamentals are construction costs and number of units sold, and the demand-based fundamentals are average gross wage, average rental price and average interest rate. 
The information about average gross income has been obtained from the State Statistical Office Reports for both regional and city levels. We have expressed gross income in euro currency in order to avoid inflator influence and mistakes in value comparison. The information regarding average square meter price and construction costs per square meter have been collected through questionnaires distributed to construction companies and real estate agencies. The precondition for accepting data was defined through tracking record which cannot be shorter than seven years (2007/2013), because we wanted to collect comparable data and to avoid 'one-project' companies - the ones with a single constructed real estate after which they were closed. The same preconditions stand for real estate agencies when we sent them questionnaires about the average square meter price and number of units sold. Regarding the number of construction companies and real estate agencies, the sample reached $77 \%$ of sent questionnaires. The share of $23 \%$ did not respond or fulfil the requirement of tracking record. The average interest rate on mortgage loans was calculated through questionnaires sent to all 32 local branches. We have received answers from 25 banks with 7-year experience in providing mortgage loans.

The first method we used in our research was a multiple regression model to explain the relationship between defined fundamentals and a dependent variable. However, results showed a lack of statistical significance, making impossible to draw conclusions about the relations between the observed variables.

Another method we employed was a linear regression model which combines each independent variable with a dependent one. The linear regression model is a statistical tool for modelling the relationship between a scalar dependent variable $y$ and one or more explanatory variables denoted $X$. In our research we have used a simple linear model, combining each independent with a dependent variable. The basic model of simple linear regression is $f(x)=$ $\alpha+\beta x$, and it combines $n$ couples of $\mathrm{x}$ and $\mathrm{y}\left\{\left(\mathrm{x}_{1}, \mathrm{y}_{1}\right),\left(\mathrm{x}_{2}, \mathrm{y}_{2}\right)\left(\mathrm{x}_{3}, \mathrm{y}_{3}\right)\left(\mathrm{x}_{\mathrm{n}}, \mathrm{y}_{\mathrm{n}}\right)\right\}$ so the expansion is $f(x)=\alpha+\beta x+\varepsilon$. In the simple linear model, variable $\mathrm{Y}$ depends on variable $\mathrm{X}$, unknown values of $\alpha$ and $\beta$ and $\varepsilon$ which denotes non-systematic influences on Y and makes model statistical (Sosic,2006). Also, literature is defining a model with estimated parameters, denoted as $\mathrm{y}=a+b x$, where $a$ is constant and $b$ is coefficient of regression. The constant $a$ is regression function value if the independent variable equals zero and for our research it has no particular significance. On the other side, $b$ represents changes in linear regression values of dependent variable caused by changing in the independent one. Regression coefficient $(b)$ shows how changes in independent variable (X) for a single unit influence changes in the dependent variable (Y) (Sosic, 2006).

At the end of the research, we applied Step Wise regression model in order to analyze which variable is the most influencing one and can be used in prediction of future dependent variable movements. Step Wise regression 
enables to eliminate variables which overlap with others and therefore contributes to a small extent or not at all to accuracy of forecasting of this model. As a result of this approach we receive a new model with a smaller number of independent variables, which is equally good as the model with all independent variables. This model requires two significance levels: one for adding variables and one for removing variables. The cut-off probability for adding variables should be less than the cut-off probability for removing variables; such procedure provides not getting into an infinite loop.

In the literature, two most common ratios for identifying a bubble are real estate price to income ratio and rent price to real estate price ratio. Many studies have shown that income is the main initiator of the growth of demand for real estate, and in this context a bubble can be identified using price-to-income ratio (Black, Fraser, Hoesli, 2006). Along with the statistical model in our research, we have used a ratio between rental price and square meter price, so called price-rent ratio (PR ratio) useful for detecting bubbles (Himmelberg et al., 2005). The ratio shows how profitable it is to invest in real estate by comparing with other asset classes.

The ratio is calculated using the formula:

$$
P R \text { ratio }=\frac{\text { rent price }}{\text { real estate price }} \times 100
$$

The formula can be modified using price and rental price per square meter, so the formula has the following expression:

$$
P R \text { ratio }=\frac{\text { rent price per sqm }}{\text { real estate price per } s q m} \times 100
$$

The price-rent ratio is a useful tool for measuring asset profitability. Every investment in assets needs to be checked, comparing to the other class of assets. Depending on risk preferences, investors prepare investment strategy and invest their money in different classes of assets. The price-rent ratio shows relation between rents, as dividends, and real estate value, as an investment, so the present values of future cash flows are seen as a tool for revealing 'bubble' on the market. In situations when the rents are below other assets' dividends at the same level of risk, but with higher prices, it can be said that 'bubble' is present.

\section{Empirical Data}

Based on the analysis of trends on real estate markets in the world, where prices oscillated considerably and where the existence of a bubble was proved, and the real estate market in Kragujevac and its characteristics, the data have been collected with the aim of identifying the existence of a bubble in the local real estate market. The values of fundamental factors are given in the Table 1. 
The collected information during the observed period shows the following values $-19.39 \%$ increase in housing price, with the peak in 2010 reaching 931.53 euro per square meter. The highest increase on yearly basis happened in 2008 if compared to 2007, with a 99.69 euro increase per square meter. The biggest drop on yearly basis happened in 2011 compared to 2010, with the decrease of 74.74 euro per square meter. If we observe the rental price per square meter, we can see an increase until 2010 and a big drop in 2013, reaching the level of rental condition at the begging of the observed period. The number of units sold appeared to show a constant drop after 2008, when the peak was reached with 301 units sold.

Table 1 Data Sample, 2007-2013

\begin{tabular}{||c|c|c|c|c|c|c||}
\hline \hline Year & $\begin{array}{c}\text { Average sqm } \\
\text { prices (EUR) }\end{array}$ & $\begin{array}{c}\text { Average } \\
\text { rental } \\
\text { price per } \\
\text { sqm } \\
\text { (EUR) }\end{array}$ & $\begin{array}{c}\text { Number } \\
\text { of units } \\
\text { sold }\end{array}$ & $\begin{array}{c}\text { Construction } \\
\text { costs per sqm } \\
\text { (EUR) }\end{array}$ & $\begin{array}{c}\text { Average } \\
\text { interest } \\
\text { rate on } \\
\text { mortgage } \\
\text { loans }\end{array}$ & $\begin{array}{c}\text { Average } \\
\text { gross } \\
\text { wage }\end{array}$ \\
\hline 2007 & 707,14 & 3,30 & 255 & 620,40 & 7,81 & 417 \\
\hline 2008 & 806,83 & 3,95 & 301 & 615,70 & 6,51 & 480 \\
\hline 2009 & 864,08 & 4,42 & 164 & 585,70 & 5,51 & 439 \\
\hline 2010 & 931,53 & 4,38 & 203 & 540,30 & 5,38 & 471 \\
\hline 2011 & 856,82 & 4,25 & 165 & 546,60 & 5,01 & 490 \\
\hline 2012 & 870,47 & 4,18 & 163 & 551,54 & 4,57 & 476 \\
\hline 2013 & 844,29 & 3,34 & 103 & 565,50 & 4,56 & 505 \\
\hline
\end{tabular}

Source: Statistical Office of the Republic of Serbia, authors' calculation, 2014

The information regarding construction costs per square meter showed a constant drop due to the increase in efficiency in construction organization, decrease in material expenses and greater scope of application of new technologies. The construction costs per square meter fell from 620.40 in 2007 to 565.50 in 2013.

Interest rate followed suit with drop from $7.81 \%$ in 2007 to $4.56 \%$ in 2013 , which meant cheaper real estate loans. The average interest rates for housing loans in Serbia are most often connected with Euribor, the European international reference rate, which in the recent years, and above all since 2008, has had a significant falling tendency. The income, measured by gross wage, experienced increase from 417 euro in 2007 up to 505 in 2013.

The rental conditions and profitability, measured with price-rent ratio, show the unchanged situation because of parallel increase in rental prices and prices per square meter. Namely, with the rise of rental prices, the prices of real estate also rose, so that PR ratio shows similar values (Table 2). 
Table 2 PR ratio, 2007-2013

\begin{tabular}{|r|r|r|r|r|r|r|r|}
\hline Year & 2007 & 2008 & 2009 & 2010 & 2011 & 2012 & 2013 \\
\hline PR Ratio & $5.60 \%$ & $5.86 \%$ & $6.13 \%$ & $5.64 \%$ & $5.95 \%$ & $5.76 \%$ & $4.74 \%$ \\
\hline
\end{tabular}

Source: Authors' calculation, 2014

PR ratio data is significant if we compare it with investment at the same risk level. The literature defines bank's deposits and T-bills as the safest investment in one country. During the observed period, bank's deposit interest rate was $8.03 \%$ on average, according to the World Bank. At the same time investment in T-bills, noted in Euro for one year (2012), brought $6.15 \%$, according to the National Bank Report on Public debt. As a result, a portfolio of assets with the same level of risk (or even lower) may have been made, but with higher dividends.

\section{Results and Discussion}

The results obtained in our research are presented in the tables in Appendix. The model showed a strong relation between the average square meter price and average rental price per square meter, with unstandardized coefficient $(B)$ of 171.873, standardized coefficient (Beta) of 0.943 and the significance level of 0.005. (Table $b$ ). The trends of these two variables are shown in the Figure 1.

Figure 1. Average sqm price and average rental price per sqm

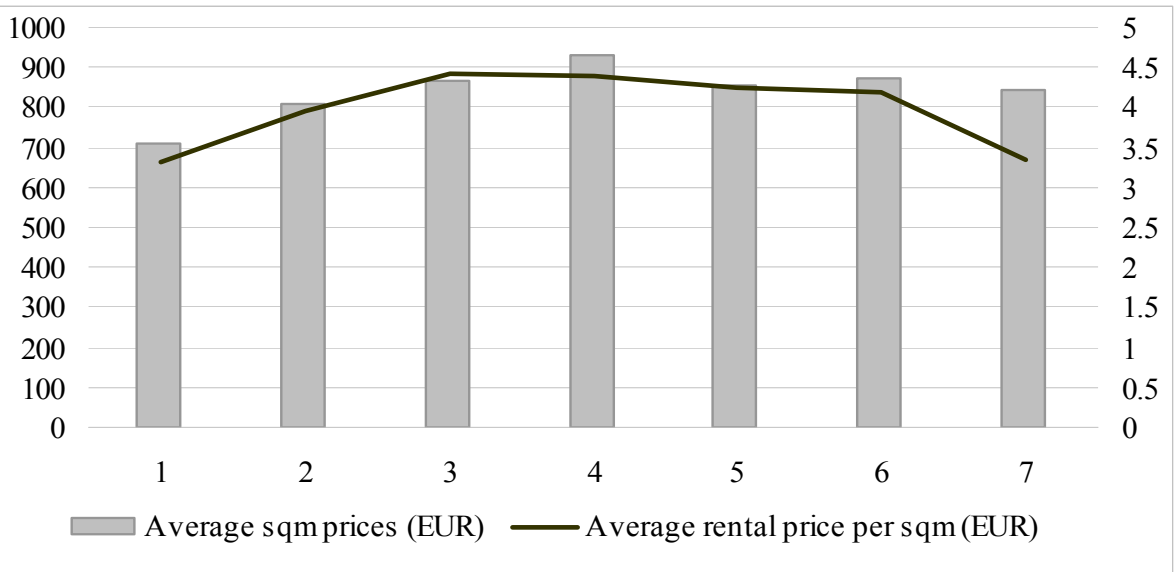

Source: Authors' calculation, 2014

The relation between two variables can be seen as rational. The demandside market appeared to behave rationally, since when rental price was up, both demand and prices rose. The asset investors see the opportunity to obtain profits 
attributable to rent increase. But, when we paid attention to PR ratio, rationality was not present because the obtained dividends did not experience a significant increase during the observed period. Besides, investors had an alternative in investment strategy with a portfolio consisting of bank's deposits and T-bills.

Two independent variables, construction costs and average interest rate, experienced statistically significant relation with the average square meter price (Tables $\mathrm{d}$ and e). The relation of these two variables, as well as the trends PR ratios are shown in Figure 2. The last two, number of units sold and average gross income, had no statistically significant relation with the defined dependent variable (Tables $\mathrm{c}$ and $\mathrm{f}$ ).

The other used method refers to Step Wise regression. Step Wise test showed that the rental price is the best variable for predicting real estate price movements in the future (Table g).

Figure 2 Average sqm price, construction costs per sqm, average interest rate on mortgage loans and PR Ratio

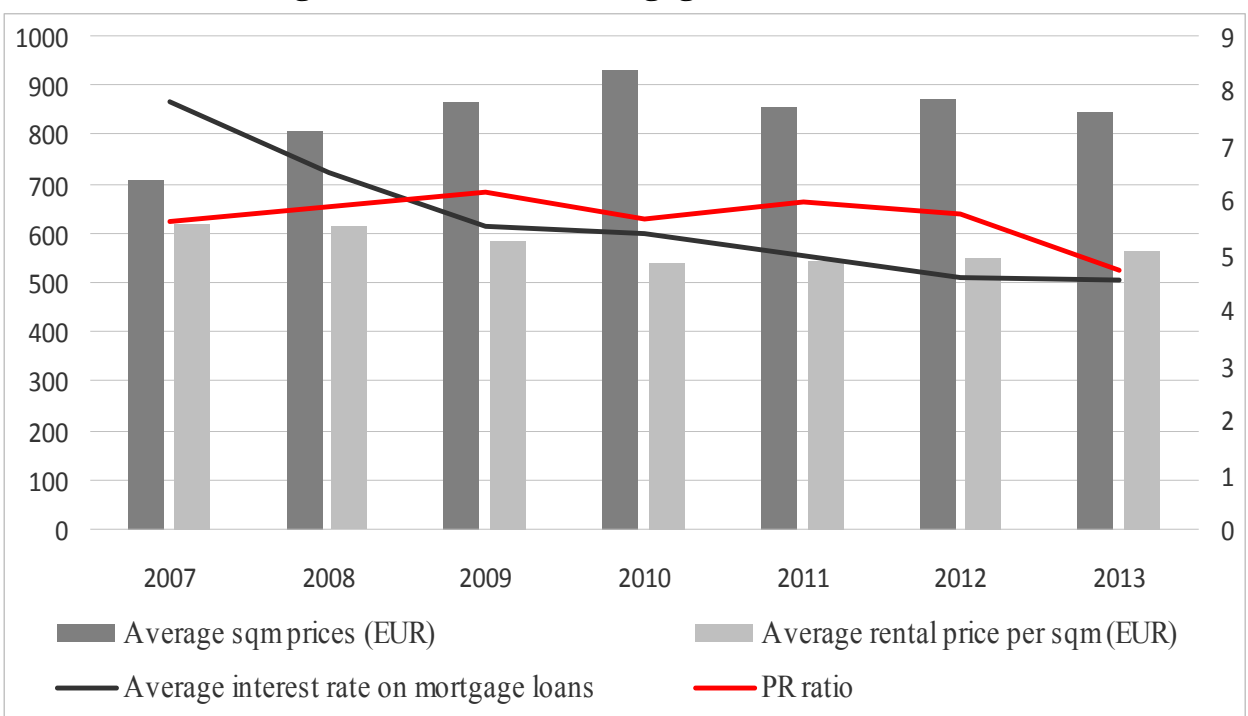

Source: Authors' calculation, 2014

The statistics showed strong demand's influence on price movements, through rental price, determined by investors' choice to buy properties as an asset which will bring profit in years to come. The main increase in price and rental price happened in 2009, 2010 and 2011 after the announcement of opening FIAT facility in Kragujevac in 2008.

The investors predicted that multinational company presence would influence constant increase in rental prices in years to come and they acted 
according to such forecast, pushing demand up and price as well. The construction costs moved in the opposite direction, similar to the USA explained by Shiller (2005). The relation with interest rate can be explained by rationality in the behaviour of real estate buyers. In situation when interest rate declines, it is normally to witness an increase in prices of real estate, loans becoming cheaper and a demand increase, pushing the prices up.

Empirical results of the research confirm the set hypotheses, i.e., that the arrival of the multinational company caused the rise of prices in the local real estate market due to irrational expectations of economic entities on the future rent prices and real estate values. Moreover, the prices of real estate cannot be explained by values of fundamental factors which are used in this research.

\section{Conclusion}

This study showed the irrational behaviour of investors resulted from an arrival of a multinational company. The arrival of FIAT caused short-term disruption in the real estate market where the growth of both prices and rents produced a bubble. Irrationality in the behaviour of the real estate buyers can be detected when comparing the return on investment with a possible yield from bank investment and state securities. Given that deposits and state securities are the safest types of investment, irrational behaviour is reflected in the pronounced impact of rents on property prices. An explanation for such buyers' behaviour is in accordance with the attitude of Robert Shiller, who pointed out to irrationality resulted from the excessive optimism of investors. Optimism can be explained by the arrival of the multinational company to Kragujevac and commencing automotive production after 20-year interval.

Also, the absence of significant effects on average wages and construction cost indicates the inconsistency in the functioning of the real estate market in Kragujevac. If there is no influence of changes in an average salary on real estate prices, financing the purchase of real estate and the origin of the money are questionable. A possible explanation may be in a real estate purchase made by investors who did not reside in Kragujevac, but estimated it a good destination for investment after the announcement of a new FIAT factory. When it comes to the cost of construction, their movement in the opposite direction from the price suggests a strong pressure of demand and profit maximization in construction companies. As a result, after a period of expansion, a large number of unsold and not completed properties remained without dwellers.

Bearing in mind the data and methodology used, we point out the limitations of the data, constricted time horizon and still underdeveloped local real estate market. In the following period, we will endeavour to develop a model able to predict the movements in real estate prices, depending on the movement of observed variables. 


\section{References}

Burnside, C., M. Eichenbaum, and S. Rebelo (2011) Understanding booms and busts in housing markets, National Bureau of Economic Research.

Black, A., P. Fraser and M. Hoesli (2006) "House prices, fundamentals and bubbles", Journal of Business Finance \& Accounting 33 (9-10), pp. 1535-1555.

Blanchard, O. J. and S. Fisher (1989) Lectures on macroeconomics. Cambridge, MA: MIT Press.

Case, K.E. and R. Shiller (2003) "Is there a bubble in the housing market?", Brookings Papers on Economic Activity 2, pp. 299-361.

Cochrane, J. (2001) Asset pricing, Princeton, Princeton University Press, New Jersey.

Flood, R. and R. Hodrick (1990) "On testing for speculative bubbles", Journal of Economic Perspectives 4(2), pp. 85-101,

Gallin, J. (2003) The long-run relationship between house prices and income: evidence from local housing markets. United States Federal Reserve Board.

Glaeser. E. L., J. Gyourko and A. Saiz (2008) "Housing supply and housing bubbles", J Urban Econ 64, pp. 198-217.

Guiso, L., M. Haliassos and T. Jappelli (2003) "Household stockholding in Europe: where do we stand and where do we go?", Economic Policy, 18 (36), pp. 123 170 .

Himmelberg, C., C. Mayer and T. Sinai (2005) “Assessing high house prices: bubbles, fundamentals and misperceptions", The Journal of Economic Perspective, 19(4), pp. 67-92.

Igan, D., A.N. Kabundi, Nadal-De Simone, F., M. Pinheiro and N. T., Tamirisa (2011) „Housing, credit and real activity cycles: characteristics and comovement”, Journal of Housing Economics 20 (3), pp. 210-231.

International Monetary Fund (2003) When bubbles burst, World Econ Outlook, Chapter 2.

Mayer, C. (2011) "Housing bubbles: a survey", Ann Rev Econ 3, pp. 559-577.

Mayer, C., K. Pence and S. M. Sherlund (2008) The rise in mortgage defaults, In: FRB Finance and Economics Discussion Series No. 59.

Mikhed, V. and P. Zemcik (2009) "Do house prices reflect fundamentals? Aggregate and panel data evidence", Journal of Housing Economics, 18(2), pp. 140-149.

Quigley, J. M. (1999) "Real estate prices and economic cycles", International Real Estate Review, 2(1), pp. 1-20.

Roche, M. J. (2001) "The rise in house prices in Dublin: bubble, fad or just fundamentals", Economic Modelling, 18, pp. 281-295.

Shen, Y., E. C. M. Hui and H. Liu (2005) "Housing price bubbles in Beijing and Shanghai", Management Decision, 43(4), pp. 611.

Shiller, R. J. (2000) Irrational Exuberance, Princeton University Press.

Shiller, R. J. (2005) Irrational Exuberance, $2^{\text {nd }}$ Edition, Princeton University Press.

Stiglitz, J. (1990) "Symposium on bubbles", The Journal of Economic Perspectives, 4(2), pp. 13-18.

Šošić, I., (2006) Primenjena statistika, Školska knjiga, Zagreb. 
Narodna banka Srbije, (2014)

http://www.nbs.rs/static/nbs_site/gen/latinica/90/dinarizacija/din_06_14.pdf

Republički zavod za statistiku, (2014) www.stat.gov.rs/

World Bank Data on Real interest rate (\%) available on: www.data.worldbank.org/indicator/FR.INR.DPST

\title{
MOGUĆNOST STVARANJA „MEHURA” NA LOKALNOM TRŽIŠTUU NEKRETNINA USLED DOLASKA MULTINACIONALNE KOMPANIJE: PRIMER FIJATA I GRADA KRAGUJEVCA
}

\begin{abstract}
Apstrakt: Cilj rada je analiza nedavnog značajnog povećanja cene nekretnina u Kragujevcu, koje se može dovesti u vezu sa dolaskom multinacionalne kompanije. Glavno pitanje je da li je porast cena nekretnina bio izazvan fundamentalnim faktorima ili špekulativnim ponašanjem subjekata na tržištu. U radu su faktori koji utiču na cenu nekretnina dekomponovani na faktore na strani ponude i faktore na strani tražnje sa ciljem otkrivanja „mehura“ i ukazivanja na iracionalno ponašanje investitora (građevinskih kompanija i kupaca). Rezultati ukazuju na nedostatak racionalnog ponašanja subjekata na tržištu, odsustvo uticaja fundamentalnih faktora na cenu nekretnina i nerealan rast ovih cena. Takođe, uočena je jaka veza između cene nekretnina i cene izdavanja nekretnina bez značajne promene PR racia.
\end{abstract}

Ključne reči: tržište nekretnina, fundamentalni faktori, PR racio, iracionalna očekivanja, multinacionalna kompanija 


\section{Appendix}

a) Descriptive statistics

\begin{tabular}{|c|c|c|c|c|c|c|c|}
\hline & & $\begin{array}{l}\text { Average } \\
\text { sqm price }\end{array}$ & $\begin{array}{l}\text { Average } \\
\text { rental } \\
\text { price per } \\
\text { sqm }\end{array}$ & $\begin{array}{l}\text { Number } \\
\text { of units } \\
\text { sold }\end{array}$ & $\begin{array}{l}\text { Constructi } \\
\text { on costs } \\
\text { per sqm }\end{array}$ & $\begin{array}{c}\text { Aevrage } \\
\text { interest rate } \\
\text { on } \\
\text { mortgage } \\
\text { loans } \\
\end{array}$ & $\begin{array}{l}\text { Average } \\
\text { gross wage }\end{array}$ \\
\hline \multirow{2}{*}{$\mathrm{N}$} & Valid & 6 & 6 & 6 & 6 & 6 & 6 \\
\hline & Missing & 0 & 0 & 0 & 0 & 0 & 0 \\
\hline \multicolumn{2}{|c|}{ Mean } & 839.4783 & 4.0800 & 208.5000 & 57670.666 & 5.7983 & 462.1667 \\
\hline \multicolumn{2}{|c|}{ Median } & 860.4500 & 4.2150 & 184.0000 & 56862.000 & 5.4450 & 473.5000 \\
\hline \multicolumn{2}{|c|}{ Mode } & $707.14^{\mathrm{a}}$ & $3.30^{\mathrm{a}}$ & $163.00^{\mathrm{a}}$ & $54030.00^{\mathrm{a}}$ & $4.57^{\mathrm{a}}$ & $417.00^{\mathrm{a}}$ \\
\hline \multicolumn{2}{|c|}{ Std. Deviation } & 76.05171 & .41709 & 57.77802 & 3570.9061 & 1.17828 & 28.06718 \\
\hline \multicolumn{2}{|c|}{ Variance } & 5783.863 & .174 & 3338.300 & 12751370. & 1.388 & 787.767 \\
\hline \multicolumn{2}{|c|}{ Skewness } & -1.038 & -1.673 & .976 & .342 & 1.112 & -1.004 \\
\hline \multicolumn{2}{|c|}{$\begin{array}{l}\text { Std. Error of } \\
\text { Skewness } \\
\end{array}$} & .845 & .845 & .845 & .845 & .845 & .845 \\
\hline \multicolumn{2}{|c|}{ Kurtosis } & 1.723 & 2.837 & -.617 & -2.400 & .771 & -.392 \\
\hline \multicolumn{2}{|c|}{$\begin{array}{l}\text { Std. Error of } \\
\text { Kurtosis }\end{array}$} & 1.741 & 1.741 & 1.741 & 1.741 & 1.741 & 1.741 \\
\hline
\end{tabular}

b) Linear regression average sqm price/average rental price per sqm

\begin{tabular}{|c|c|c|c|c|c|c|}
\hline \multicolumn{7}{|c|}{ Coefficients $^{\mathrm{a}}$} \\
\hline \multirow{2}{*}{\multicolumn{2}{|c|}{ Model }} & \multicolumn{2}{|c|}{$\begin{array}{l}\text { Unstandardized } \\
\text { Coefficients }\end{array}$} & \multirow{2}{*}{$\begin{array}{c}\begin{array}{c}\text { Standardized } \\
\text { Coefficients }\end{array} \\
\text { Beta }\end{array}$} & \multirow[t]{2}{*}{$\mathrm{t}$} & \multirow[t]{2}{*}{ Sig. } \\
\hline & & $\mathrm{B}$ & Std. Error & & & \\
\hline \multirow[b]{2}{*}{1} & (Constant) & 138.235 & 124.758 & & 1.108 & .330 \\
\hline & $\begin{array}{c}\text { average rental price } \\
\text { per }\end{array}$ & 171.873 & 30.446 & .943 & 5.645 & .005 \\
\hline
\end{tabular}

a. Dependent Variable: average sqm price

\begin{tabular}{|c|c|c|c|c|c|c|c|c|c|}
\hline \multicolumn{1}{|c|}{ Model } & $R$ & $R$ & Adjusted & $\begin{array}{c}\text { Std. Error } \\
\text { of the } \\
\text { Estimate }\end{array}$ & $\begin{array}{c}R \\
\text { Square } \\
\text { Change }\end{array}$ & $F$ Change & $d f 1$ & $d f 2$ & $\begin{array}{c}\text { Sig. } F \\
\text { Change }\end{array}$ \\
\hline 1 & $.943^{a}$ & .888 & .861 & 28.39460 & .888 & 31.869 & 1 & 4 & .005 \\
\hline \multicolumn{10}{|c|}{ a. Predictors: (Constant), average rental price per sqm } \\
\hline \multicolumn{10}{|c|}{ b. Dependent Variable: average sqm price } \\
\hline
\end{tabular}




\begin{tabular}{|c|c|c|c|}
\hline \multicolumn{4}{|c|}{ Correlations } \\
\hline \multicolumn{2}{|c|}{} & $\begin{array}{c}\text { average } \\
\text { prices off } \\
\text { sqm }\end{array}$ & $\begin{array}{c}\text { average rental } \\
\text { price per }\end{array}$ \\
\hline \multirow{3}{*}{$\begin{array}{c}\text { average sqm price } \\
\text { Pearson Correlation }\end{array}$} & 1 & $.943^{* *}$ \\
\cline { 2 - 4 } $\begin{array}{c}\text { average rental price per } \\
\text { sqm }\end{array}$ & Sig. (2-tailed) & 6 & .005 \\
\cline { 2 - 4 } & Pearson Correlation & $.943^{* *}$ & 6 \\
\cline { 2 - 4 } & Sig. (2-tailed) & .005 & 1 \\
\cline { 2 - 4 } & N & 6 & 6 \\
\hline \multirow{2}{*}{$* *$ Correlation is significant at the 0.01 level (2-tailed). } \\
\hline
\end{tabular}

c) Linear regression average sqm price/number of units sold

\begin{tabular}{|c|c|c|c|c|c|c|c|}
\hline \multicolumn{8}{|c|}{ Model Summary and Parameter Estimates } \\
\hline \multicolumn{8}{|c|}{ Dependent Variable: average sqm price } \\
\hline \multirow[t]{2}{*}{ Equation } & \multicolumn{5}{|c|}{ Model Summary } & \multicolumn{2}{|c|}{ Parameter Estimates } \\
\hline & R Square & $\mathrm{F}$ & $\mathrm{df1}$ & $\mathrm{df} 2$ & Sig. & Constant & b1 \\
\hline $\begin{array}{c}\text { Logarithmi } \\
\text { c }\end{array}$ & .346 & 2.120 & 1 & 4 & .219 & 1746.042 & -170.721 \\
\hline
\end{tabular}

\begin{tabular}{|c|c|c|c|}
\hline \multicolumn{4}{|c|}{ Correlations } \\
\hline \multirow{3}{*}{ average sqm price } & $\begin{array}{c}\text { average prices } \\
\text { off sqm }\end{array}$ & number off sold \\
\hline & Pearson Correlation & 1 & -.589 \\
\cline { 2 - 4 } & Sig. (2-tailed) & & .219 \\
\cline { 2 - 4 } & $\mathrm{N}$ & 6 & 6 \\
\hline \multirow{3}{*}{ number of units sold } & Pearson Correlation & -.589 & 1 \\
\cline { 2 - 4 } & Sig. (2-tailed) & .219 & 6 \\
\cline { 2 - 4 } & $\mathrm{N}$ & 6 & \\
\hline
\end{tabular}

d) Linear regression average sqm/construction costs per sqm

\begin{tabular}{|c|c|c|c|c|c|c|c|c|}
\hline \multicolumn{9}{|c|}{ Model Summary and Parameter Estimates } \\
\hline \multicolumn{9}{|c|}{ Dependent Variable: average sqm price } \\
\hline \multirow[t]{2}{*}{ Equation } & \multicolumn{5}{|c|}{ Model Summary } & \multicolumn{3}{|c|}{ Parameter Estimates } \\
\hline & $\begin{array}{c}\mathrm{R} \\
\text { Square }\end{array}$ & $\mathrm{F}$ & df1 & $\mathrm{df} 2$ & Sig. & Constant & $\mathrm{b} 1$ & $\mathrm{~b} 2$ \\
\hline Quadratic & .764 & 4.855 & 2 & 3 & .115 & -7632.135 & .311 & $\begin{array}{c}2.829 \mathrm{E} \\
-006\end{array}$ \\
\hline
\end{tabular}




\begin{tabular}{|c|c|c|c|}
\hline \multicolumn{4}{|c|}{ Correlations } \\
\hline \multirow{3}{*}{ average sqm price } & $\begin{array}{c}\text { average prices } \\
\text { off sqm }\end{array}$ & $\begin{array}{c}\text { price off } \\
\text { housing constr }\end{array}$ \\
\cline { 2 - 4 } & Pearson Correlation & 1 & $-.846^{*}$ \\
\cline { 2 - 4 } & Sig. (2-tailed) & & .034 \\
\hline \multirow{3}{*}{ Construction costs per sqm } & N & 6 & 6 \\
\cline { 2 - 4 } & Pearson Correlation & $-.846^{*}$ & 1 \\
\cline { 2 - 4 } & Sig. (2-tailed) & .034 & 6 \\
\cline { 2 - 4 } & N & 6 & \\
\hline \multirow{2}{*}{$*$ *. Correlation is significant at the 0.05 level (2-tailed). } \\
\hline
\end{tabular}

e) Linear regression average sqm price/average interest rate on mortgage loans

\begin{tabular}{|c|c|c|c|c|c|c|c|c|}
\hline \multicolumn{8}{|c|}{ Model Summary and Parameter Estimates } \\
\hline \multicolumn{8}{|c|}{ Equation } & \multicolumn{7}{c|}{ Modent Variable: average sqm price } \\
\cline { 2 - 9 } & R Square & F & df1 & df2 & Sig. & Constant & b1 & b2 \\
\hline $\begin{array}{c}\text { Quadrati } \\
\text { c }\end{array}$ & .856 & 8.910 & 2 & 3 & .055 & 296.744 & $\begin{array}{c}231.9 \\
87\end{array}$ & $\begin{array}{c}23.07 \\
2\end{array}$ \\
\hline \multicolumn{7}{|c|}{ The independent variable: average interest rate on mortgage loans } \\
\hline
\end{tabular}

\begin{tabular}{|c|c|c|c|}
\hline \multicolumn{4}{|c|}{ Correlations } \\
\hline & & $\begin{array}{l}\text { average prices } \\
\text { off sqm }\end{array}$ & average interes \\
\hline \multirow{3}{*}{ average sqm price } & Pearson Correlation & 1 & $-.863^{*}$ \\
\hline & Sig. (2-tailed) & & .027 \\
\hline & $\mathrm{N}$ & 6 & 6 \\
\hline \multirow{3}{*}{$\begin{array}{l}\text { average interset rate on } \\
\text { mortgage }\end{array}$} & Pearson Correlation & $-.863^{*}$ & 1 \\
\hline & Sig. (2-tailed) & .027 & \\
\hline & $\mathrm{N}$ & 6 & 6 \\
\hline
\end{tabular}

f) linear regression average sqm price/average gross wage

\begin{tabular}{|c|c|c|c|c|c|c|c|c|}
\hline \multicolumn{7}{|c|}{ Model Summary and Parameter Estimates } \\
\hline \multirow{2}{*}{ Equation } & \multicolumn{7}{|c|}{ Modendent Variable: average sqm price } \\
\cline { 2 - 8 } & R Square & F & df1 & df2 & Sig. & Constant & b1 & b2 \\
\hline $\begin{array}{c}\text { Quadrati } \\
\text { c }\end{array}$ & .769 & 4.994 & 2 & 3 & .111 & $\begin{array}{c}19648.44 \\
5\end{array}$ & 89.086 & -.097 \\
\hline \multicolumn{7}{|c|}{ The independent variable: average gorss wage } \\
\hline
\end{tabular}




\begin{tabular}{|c|c|c|c|}
\hline \multicolumn{4}{|c|}{ Correlations } \\
\hline \multirow{2}{*}{} & $\begin{array}{c}\text { average prices } \\
\text { off sqm }\end{array}$ & $\begin{array}{c}\text { the average } \\
\text { gross }\end{array}$ \\
\hline \multirow{3}{*}{ average sqm price } & Pearson Correlation & 1 & .614 \\
\cline { 2 - 4 } & Sig. (2-tailed) & & .195 \\
\cline { 2 - 4 } & $\mathrm{N}$ & 6 & 6 \\
\hline \multirow{3}{*}{ average gorss wage } & Pearson Correlation & .614 & 1 \\
\cline { 2 - 4 } & Sig. (2-tailed) & .195 & 6 \\
\cline { 2 - 4 } & $\mathrm{N}$ & 6 & \\
\hline
\end{tabular}

g) Step Wise regression

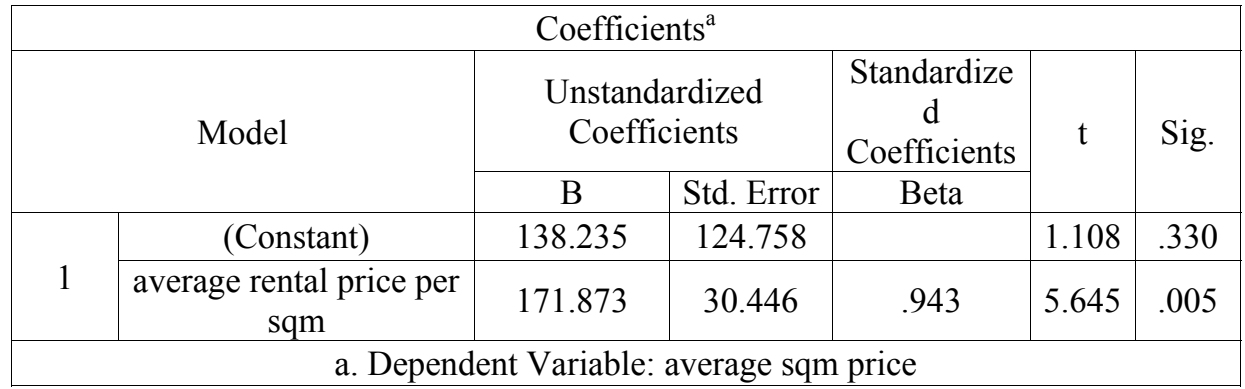

